\title{
A Focus Group Qualitative Analysis on the Real-time Online Learning Experience of Students Majoring in Speech-Language Pathology and Audiology
}

\author{
JiYoun Kim, PyungKon Tark, SooBok Lee \\ Department of Speech-Language Therapy \& Aural Rehabilitation, Woosong University, Daejeon, Korea
}

Correspondence: SooBok Lee, PhD Department of Speech-Language Therapy \& Aural Rehabilitation, Woosong University, 171 Dongdaejeon-ro, Dong-gu, Daejeon 34606, Korea Tel: $+82-42-630-9222$

Fax: +82-42-630-9229

E-mail: sblee@wsu.ac.kr

Received: July 5, 2021

Revised: July 31, 2021

Accepted: August 10, 2021

This research was conducted by the 2021 Woosong University in school academic research grant fund support.
Objectives: This purpose of this study was to examine the perceptions of students who majored in Speech Therapy and Audiology Rehabilitation in relation to the real-time online learning experience using zoom conducted during the COVID-19 pandemic, and to find a way to increase the effectiveness of non-face-to-face lectures in the future. Methods: Focus group interviews were conducted twice with 10 students (5 each) majoring in Speech Therapy and Audiology Rehabilitation. The questionnaire for the focus group interview consisted of 21 questions in 4 areas; including interaction, lecture content, lecture system, and comprehensive opinion, and the interview was conducted for 90 minutes for each group. Results: As a result of open-coding and analyzing the real-time online learning experiences of the study participants, 190 semantic units, 44 subcategories, and 10 core categories were derived. And the 10 core categories were divided into three dimensions: the personal dimension, the environmental dimension, and the pedagogical dimension. The results of the study confirmed the various opinions and desires of students for real-time online learning during the COVID-19 period. Conclusion: This study will provide a basis for building an effective real-time online teaching method and practical training system for field practice, and will further improve the educational effectiveness of education in the department of Speech Therapy and Audiology Rehabilitation

Keywords: COVID-19, Speech-Language Pathology and Audiology, Real-time online learning, Non-face-to-face lecture, Focus group interview, Qualitative research
4 차산업혁명시대의 도래와 정보통신기술의 발달은 인간의 삶을 크게 변화시키고 있으며, 코로나바이러스 감염증(Corona Virus Disease 19, COVID-19)의 확산으로 교육 영역에서도 이러한 변화 를 가져오고 있다. 최근 10 년간 대학에서 이러닝(e-learning) 교육 은 확대되어 왔으며, 온라인 강의 활용과 이러닝을 통한 학점교류 뿐만 아니라 공유대학(e-dhnews, 2021) 등의 제도를 정부에서 정책 적으로 지원하고 확대하면서 온라인 강의 개선 및 확산에 대한 관 심이 높아지고 있다(Choi \& Roh, 2011). 코로나19 이전에도 2011년 설립된 해외 미네르바스쿨의 경우는 $100 \%$ 온라인 수업을 실시하 였으나, 국내 대학들은 일부 수업을 대상으로 온라인 수업을 실시 하는 정도였고, 코로나19가 확산되면서 교육부가 비대면수업을 권 고하면서 대면수업 중심의 교육을 실시하던 국내 대학들은 기존
교육 방식을 대부분 원격수업으로 전환하면서 교육형태와 방식 등 의 운영에 갑작스러운 변화를 경험하고 있다.

대학가에서 진행된 원격수업은 크게 실시간 수업과 비실시간 수 업 두 가지로 구분된다(Song \& Kim, 2020). 실시간 원격수업은 화 상회의 플랫폼을 활용하여 실시간으로 교수자와 학습자 간 상호작 용이 활발히 이루어지고 교수자가 학습자를 통제하고 관리하기가 비교적 쉽다는 장점을 가지고 있는 반면, 학습자의 입장에서 정해 진 시간에 수업을 들어야 하며, 반복 학습을 하지 못한다는 단점을 보인다. 비실시간 원격수업은 교수자가 강의하는 모습을 촬영하거 나 수업자료에 교수자의 음성을 입힌 콘텐츠를 공유함으로써 원하 는 시간과 장소에서 수업을 들을 수 있어 시간 및 공간적 제약이 없 으며, 반복 학습이 가능하다는 이점이 있다. 그러나 교수자-학습자 
의 상호작용에 다소 어려움을 보일 수 있으며 학습자에 대한 관리 가 어렵다는 한계를 갖고 있다. 이러한 실시간, 비실시간 원격수업 의 한계를 극복하고자 블렌디드 러닝(blended learning), 플립러닝 (flipped learning) 등의 혼합 수업 유형이 적용되고 있다(Cho, 2020).

최근에는 원격수업 환경에서 기존의 제한점을 보완할 수 있도록 교수자와 학습자 간 실시간 상호작용이 가능한 실시간 원격수업이 널리 사용되고 있다. 원격수업이 기초적인 지식을 형성하는 데에는 전통적인 강의 방식과 그 효율성에서 크게 다르지 않다는 연구결 과들이 있다(Krimm, Schule, \& Brame, 2017).

보건의료계열 전공에서 원격수업이 전통적인 대면수업 방식만 큼 성공을 거두었다는 것을 논증하는 연구들이 계속되고 있는 추 세이다. 간호학에서 근육 주사에 대한 기술과 지식 습득에서 원격 수업을 했던 학생들이 더 높은 점수를 받았다고 하였다 $(\mathrm{Lu}, \mathrm{Lin}, \&$ $\mathrm{Li}, 2009)$. 심리학 전공 수업에서 전통적인 대면수업과 원격수업을 비교한 Fredericksen, Pickett, Shea, Pelz와 Swan (2000)의 연구에 의하면 원격수업을 통해 전통적인 강의실에서 하는 대면수업만큼 수업 완성도가 이루어졌으며 전통적인 강의를 수강한 학생들이 수 업 내용의 $78 \%$ 를 기억한 반면, 원격강의를 수강한 학생들은 $82 \%$ 를 기억함으로써 화상을 통한 원격수업 방식이 학생들의 배운 지식 을 기억하는 측면에서 더 효율적이라고 하였다. 반면 Wang과 New$\operatorname{lin}$ (2000) 역시 심리학 전공 대학생들에게 비슷한 연구를 실시하였 는데 이 연구에서는 오히려 전통적인 대면강의 방식의 수업을 들은 학생들의 기말 성적이 실시간 원격강의를 수강한 학생들보다 통계 적으로 유의하게 더 높았다고 하였다. 이와 같은 상반된 연구결과 에 대해, 연구자들은 학습자의 학습 동기, 교수자와 학습자의 상호 작용, 기술적인 지원 등이 원격강의의 성공 여부에 영향을 미친다 고 하였다(Fredericksen et al., 2000).

보건의료계열 전공인 언어치료청각재활 전공은 이론적인 지식 습득과 함께 교수자와 학습자의 상호작용이 요구되며 임상 관찰 및 실습을 이수해야 하므로 다른 분야에 비해서는 원격수업이 활 발하게 진행되지 못하였다. 그리하여 미국이나 호주의 경우 일부 대학에서 언어치료청각재활 분야에서 원격수업이 이루어지고 있 었으며 국내 사이버 대학들에서 제한적으로 원격수업을 실시하고 있으나 이에 대한 학습 효과나 만족도에 대한 연구는 많지 않다. Blackwell, Roach와 Baker (2002)는 언어치료 전공 대학원생들에 게 전공 이론과 관련된 과목들을 비실시간 원격수업과 전통수업 으로 나누어 선택하게 한 후 각각의 강의를 수강한 대학원생들의 성적을 비교해보았을 때 두 집단 간에 유의한 차이는 없었으나, 학 습만족도에 있어서는 비실시간 원격수업을 수강한 대학원생들의 만족도가 더 높았다. 이에 대해 연구자들은 보다 적극적인 학생들
혹은 인터넷 기반에 익숙한 학생들이 원격수업을 선택했기 때문에 만족도가 높았을 수 있으며, 대학원생들은 깊이 있는 교육과 학습 에 대한 동기가 높으므로 학부생들의 결과와 다를 수 있음을 유의 해야 한다고 해석하였다.

최근 들어 Khoza-Shangase, Moroe와 Neille (2021)은 코로나19 로 인해 언어치료 분야의 학생들에게 적용되는 원격 임상실습 및 임상치료 효과에 대한 연구를 수행한 결과, 하이브리드 원격 임상 실습이 효과적이었으며 비용 효과가 있다는 긍정적인 결과를 보고 하였다.

원격수업의 지속적인 수강과 관련된 선행연구들의 결과들을 종 합해보면, 변인들의 세부적인 요인들과 범위에는 차이가 있었으나 일반적으로 학습자가 인식하는 원격수업의 유용성, 편리성, 수강 의도 등이 원격수업을 지속적으로 수강하는 데 영향을 주는 요인 이고 원격수업 시스템, 콘텐츠 및 운영은 학습자의 만족도와 관련하 여 상대적으로 영향을 적게 미치는 요인들이라고 밝히고 있다 (Choi \& Roh, 2011). Song과 Kim (2020) 연구에 의하면 재학생들의 온라인 강의 만족도는 학년별, 전공계열별로 유의한 차이가 있었다. 대면 임상 실습이 중요한 언어치료청각재활을 전공하는 학생 대상 으로 실시간 원격수업에 대한 인식을 살펴보는 연구는 전무한 실정 이다. 또한 최근 1 년간 원격수업으로 전환되면서 대학교육의 어려 움에 대한 2편(Do, 2020; Kim, 2020)의 질적연구를 제외하고는 대 부분 양적연구가 이루어져서, 대학에서의 원격교육에 대한 깊은 이 해를 위해서는 교육수요자의 경험에 대한 질적연구가 필요하다.

따라서 본 연구에서는 포커스 그룹 인터뷰를 통해 언어치료청각 재활학과 학부생들을 대상으로 실시간 원격수업에 참여한 학습 경 험과 시스템, 상호작용 등 학습만족도에 영향을 주는 요인 및 원격 수업과 임상실습에 대한 주관적인 인식에 대해 알아보고 앞으로 원격수업의 발전 방향에 대해 알아보고자 한다.

\section{연구방법}

\section{연구 참여자 선정}

본 연구의 참여자들은 2020 년 1 학기부터 2 학기까지 실시간 원격 수업을 들은 언어치료청각재활학과 2, 3학년 학부생들이다. 이들 은 모두 2019년도에는 대면 강의를 들었고 2020년에는 실습을 제 외한 모든 이론 과목을 실시간 원격수업을 들은 경험이 있어서 대 면수업과 원격수업의 차이점을 잘 설명할 수 있어서 연구 참여자들 로 선정을 하였다. 연구참여자들은 같은 학년으로 그룹을 형성하 여 참여자들 간의 논의가 활발히 이루어질 수 있도록 하였고, 참여 자들 모두 연구자들의 수업을 수강한 경험이 있고 수업 참여도가 
Table 1. Participants' general information

\begin{tabular}{lccccccccccc}
\hline No. & 1 & 2 & 3 & 4 & 5 & 6 & 7 & 8 & 9 & 10 \\
\hline Sex & $\mathrm{F}$ & $\mathrm{F}$ & $\mathrm{F}$ & $\mathrm{F}$ & $\mathrm{M}$ & $\mathrm{F}$ & $\mathrm{M}$ & $\mathrm{F}$ & $\mathrm{F}$ & $\mathrm{M}$ \\
Age & 20 & 20 & 20 & 20 & 20 & 21 & 23 & 21 & 21 & 24 \\
Grade & 2 & 2 & 2 & 2 & 2 & 3 & 3 & 3 & 3 & 3 \\
Hometown & Changwon & Ilsan & Gunsan & Chilgok & Daejeon & Seoul & Taean & Asan & Suncheon & Jincheon \\
Average grade & 3.86 & 4.32 & 4.11 & 4.29 & 4.0 & 3.95 & 3.45 & 4.39 & 4.13 & 3.82 \\
\hline
\end{tabular}

좋아 연구자들과의 관계 형성이 비교적 잘 된 학생들로 구성되었 다. 참여자들은 2 학년의 경우 신경언어장애, 유창성장애, 조음장 애, 노인청각학, 행동청능평가실습 등의 과목을 수강하였고, 3학년 의 경우는 언어재활관찰, 의사소통장애진단및평가, 언어진단실습, 인공와우평가및적합 등을 수강하였다. 또한, 3 학년 학생들의 언어 진단실습은 원격실습 경험이 있는 학생들로 선발하였다.

인터뷰를 시작하기 전에 참여자들에게 연구의 목적과 의의 취지 등을 설명한 후 10 명에게서 연구 참여 동의를 받았다. 연구 참여자 들의 인구 사회학적 특성은 Table 1과 같다.

또한, 수업만족도에 영향을 미치는 교수자들의 자격 요건은, 언 어치료분야 2 명 교수는 모두 언어병리학 전공자로 석박사학위와 언어재활사 1 급자격증 소지자이며 10 년 이상의 강의 및 임상 경험 을 가지고 있고, 청각재활분야의 교수는 청각학 전공자로 박사학 위를 소지하고 10 년 이상의 강의 경험과 임상 경험을 가지고 있다.

\section{연구의 엄격성 확보 및 윤리적 고려}

질적연구에서는 연구자와 연구 참여자들 간의 개인적 접촉이 깊 이 이루어질 수 있기 때문에 몇 가지 윤리적인 문제에 신중할 필요 가 있다. 연구 참여자들은 개인적 비밀과 익명성이 보장된다는 점 을 알아야 할 권리가 있으며, 만약 어떤 이유로 정보의 비밀을 유지 하기 어렵다면 그 점을 분명하게 알려주어야 한다. 그래서 본 연구 자는 연구 참여자의 익명성과 비밀 유지에 대한 내용을 연구 참여 동의서를 통해 약속하였으며, 연구 참여자의 인권보호에 최선을 다 하였다. 연구자는 자료수집 전에 이러한 문제들에 대해 철저히 사 전 점검하고 참여자들이 이해할 수 있도록 연구의 목적과 의미에 대해서 설명해 주었다. 또한 포커스 그룹 인터뷰 도중 대답하기 어 려운 질문에 대해서는 대답하지 않아도 된다고 공지하였다. 일반적 으로 연구 참여자들에게 자연스럽고 솔직한 행동을 요구함에 있 어 가장 큰 방해 요인은 연구 참여자가 평가받고 있다는 느낌을 갖 게 된다는 것이므로 본 연구자는 이 점을 충분히 설득시키기 위해 노력하였다. 본 연구는 우송대학교 IRB (1041549-200407-SB-94) 승인을 받은 후 진행하였다.

\section{자료수집}

연구자들은 연구 참여자들을 학년을 기준으로 2학년, 3학년 두 그룹으로 나눠서 포커스 그룹 인터뷰를 진행하여 분석 자료를 수 집하였다. 연구 참여자들은 대면수업과 실시간 원격수업에 대한 자 신의 느낌, 두 강의의 차이점, 원격수업의 장.단점 등에 대해 구술하 였다. 연구자들이 포커스 그룹 인터뷰를 진행한 이유는 토론을 진 행시켜 연구 참여자들이 토론 주제에 어떤 의미를 부여하느냐와 그 들이 어떻게 그 의미를 타협하게 되는가를 명확히 알 수 있고 잘못 된 의견이나 극단적인 견해를 배제할 수 있도록 참가자들이 상호 체크해 균형을 취함으로써 자료수집의 질을 관리할 수 있기 때문이 다. 심층면담은 면담 내용과 반응의 일관성을 위해 2 명의 연구자가 주 저자의 연구실에서 수행했으며 한 회기에 걸쳐 약 90 분간 진행 하였다. 연구자들은 원격수업을 들으면서 겪은 연구 참여자들의 다 양한 경험을 수집하기 위해 Table 2의 질문을 토대로 반구조적 질 문지법을 활용하였다. 연구 주제와 관련된 토론은 도입, 전환 및 주 요 질문의 순서로 진행되었으며 어느 정도 일관성을 유지하면서 참 여자들의 반응을 촉진하고 참여자 반응에 따라 추가 질문을 하였 다. 자료수집은 2 학년은 2020 년 11 월 20일, 3학년은 12 월 3 일에 진행 하였다. 면담 내용은 모든 참여자들의 동의를 얻어 녹음하였다.

\section{자료분석 및 타당도}

면담이 끝난 이후 1 주 이내에 언어치료청각재활 전공 4 학년 학생 이 녹음한 내용을 그대로 전사하였다. 면담 전사 내용은 굴림체, 글 자크기 10 포인트, 줄간격 160 , 장평 100 으로 작성하였을 때 2 학년 면담은 A4용지로 30쪽, 3학년은 23쪽으로 총 53쪽에 달했다. 자료 분석은 앞에서 언급한 대학 강의 경력이 10 년 이상인 언어치료청각 재활학과 교수 3 명이 실시를 하였고 언어치료분야의 교수는 모두 언어병리학 전공자로 박사학위를 가지고 있고, 청각재활분야의 교 수는 청각학 전공자로 박사학위를 소지하고 10 년 이상의 강의 경 험과 임상 경험을 가지고 있다.

내용 분석 절차는 Krippendorff (2003)가 제안한 절차에 따라 분 석하였다. 자료분석 후 연구에 참여한 참여자 2 명에게 보여주고 분 석 내용이 자신의 경험과 일치하는지를 확인하여 분석의 타당성을 
Table 2. Questions by categories

\begin{tabular}{|c|c|}
\hline Categories & Questions \\
\hline Interaction & $\begin{array}{l}\text { Are there various learning activities in class? } \\
\text { Is time adequately provided for performing learning activities? } \\
\text { Are there opportunities in class to ask questions or comments to the professor? } \\
\text { Do you think the professor give feedback to students' questions in class? } \\
\text { How is communication with fellow students in class? } \\
\text { Are there discussions or assignments in teams? }\end{array}$ \\
\hline Lecture content & $\begin{array}{l}\text { Is the non-face-to-face lecture method appropriate in terms of educational content? } \\
\text { Does the non-face-to-face lecture method induce motivation or interest in learning? } \\
\text { Does the non-face-to-face lectures help you understand the content? } \\
\text { Were there any factors that prevented the content concentration of the non-face-to-face lecture method? } \\
\text { Do you think the class time is appropriate? } \\
\text { Do you think the evaluation method is appropriate? }\end{array}$ \\
\hline Lecture system & $\begin{array}{l}\text { Is the non-face-to-face lecture properly equipped? } \\
\text { Is an environment suitable for the non-face-to-face lecture provided? } \\
\text { Did you fully understand how to use the non-face-to-face lecture before starting the non-face-to-face lecture? } \\
\text { Is it convenient to use the non-face-to-face lecture? } \\
\text { Do you think you are making good use of the non-face-to-face lecture? }\end{array}$ \\
\hline Comprehensive opinion & $\begin{array}{l}\text { What are the advantages of non-face-to-face lectures? } \\
\text { What are the disadvantages of non-face-to-face lectures? } \\
\text { In what ways would you like non-face-to-face lectures to be improved? } \\
\text { If you choose the non-face-to-face lecture and the face-to-face lecture method, are you willing to use the non-face-to-face lecture? }\end{array}$ \\
\hline
\end{tabular}

확보하였다. 자료분석의 첫 단계는 텍스트 전체에 대한 연구자의 이해 과정으로, 연구자들은 심층면담 기록 내용을 반복하여 읽으 면서 이들의 경험이 원격수업과 관계가 되어 있는지를 검토하였다. 두 번째 단계는 의미 있는 진술(significant statement) 찾기 단계로 연구자는 참여자들이 구술한 내용을 문장으로 만들었고 이 문장 이나 어구들 중에서 원격수업과 관련된 의미 있는 진술들을 발견 하여 의미를 구성했다. 이 과정에서 각 그룹 참여자 1 명에게 이메일 회신을 통해 참여자들이 의도했던 내용이 잘 정리되었는지에 대해 확인하였다. 세 번째 단계는 연구자들은 의미진술을 개념화한 후 이 개념들 중 서로 관계있거나 유사한 것들을 결집하여 의미에 적 합한 하위범주로 추상화하였고 범주화하였다. 마지막 단계는 이러 한 범주를 개인적인 차원, 환경적인 차원, 교과적인 차원으로 구분 하여 의미진술 개념과 범주를 재배열하였다. 진술에 의미를 구성하 고 개방코딩하는 작업은 연구자들이 각자 개별적으로 실시하였으 며, 범주 생성 및 추상화는 연구자들이 함께 모여 진행하였고, 연구 자들마다 의견이 다를 경우, 토론을 통해 조정하였다

\section{연구결과}

연구 참여자들의 원격수업 경험을 분석한 결과 190 개의 의미단 위, 44 개의 하위범주, 10 개의 핵심범주가 도출되었다. 이를 개인적 차
Table 3. Core categories based on dimensions

\begin{tabular}{ll}
\hline Dimension & \multicolumn{1}{c}{ Core category } \\
\hline Personal & Negative emotion \\
& Loss of tension \\
Infringed learning rights & The importance of the learner's will \\
Environmental & Dissatisfaction with the online system environment \\
& Living environment that is not easy to adapt \\
Pedagogical & The emergence of new ways of communication \\
& Complaints about the changed grade system \\
& Fear of the road you haven't taken \\
& Preference for face-to-face interaction
\end{tabular}

원, 환경적 차원, 교과적 차원으로 분절하여 Table 3에 제시하였다.

\section{개인적 차원}

\section{원격수업으로 유발된 부정적 정서}

연구 참여자들은 원격수업을 들으면서 잘 알지 못하고 필기해야 만 하는 경우가 있고(연구 참여자 1), 강의를 듣는 척하는 경우도 있 으며(연구 참여자 2), 작년에는 수업을 열심히 들었는데 올해는 공 부를 많이 안 하는 자신 및 친구들의 모습에 대해 화가 나는(연구 참여자 7) 등 의욕 상실의 모습을 보였다. 
"듣는 척하고 있을 때가 좀 많게 되는 경우가 많은 것 같 아요(2-5)."

또한 대학에 다니는 이유를 모르겠고(연구 참여자 2), 혼 자 고민하는 시간이 많아졌으며(연구 참여자 2,3 ), 불안하기 도 하여 수업에 집중하지 못하는 모습(연구 참여자 3), 나태 해진 자신의 모습을 보고 우울증에 빠진(연구 참여자 1,5 , 8) 모습 등 연구 참여자들은 무기력에 빠진 경험을 하였다.

“그 나태해진 내 모습을 보니까? 더 우울해져요(2-48)."

이 외에도 연구 참여자들은 교수님들마다 화면을 나오게 하는 범위의 기준이 달라서 혼란스러워했고(연구 참여자 1), 화면상에서 얼굴이 잘 보이지 않아 집중을 안 하게 되고 자신의 신체 부위가 덜 나오게 화면을 조절할 만큼 화면에 보이는 자신의 모습이 어색했으 며, 화면의 필터를 바꾸었는데도 눈이 아프거나(연구 참여자 5) 더 나빠진 경험(연구 참여자 8 )을 하였다.

“화면을 뒤로 해놓으면 여기까지만 나와(6-15)."

이와 같이 원격수업을 들으면서 의욕을 상실하고, 무기력에 빠지 며, 화면에 보인 자신의 모습에 어색함을 느끼며 눈 건강이 나빠진 연구 참여자들의 경험을 '원격수업으로 인해 유발된 부정적 정서' 라고 명명하였다.

\section{긴장감의 상실}

연구 참여자들은 대면 강의가 아니므로 아침에 일찍 일어나는 것에 대한 걱정이 줄어들었다(연구 참여자 $2,3,6,10$ ). 연구 참여자 3,6 은 수업 5-10분 전에 일어나서 책상에 바로 앉아 강의를 듣기도 하였으며, 연구 참여자 10 은 아침에 전혀 준비하지 않은 상태에서 수업을 듣는 등 시간에 대한 중압감이 전혀 없었다.

“아침에 일어나자마자 들을 수 있어(10-3)."

반면 연구 참여자들은 학교에 가지 않아도 되니까 시간을 절약 할 수 있어서 좋았다고 하였다(연구 참여자 $2,4,6,7,10)$. 특히 통학 하는 학생들은 원격수업을 선호하였다(연구 참여자 7). 하지만 집 에서 강의를 듣다 보니 더 편한 곳에서 수업을 듣고자 하는 생각들 이 간절하여(연구 참여자 $1,2,5)$ 침대에서 누워서 수업을 듣는 경 우도 있었다(연구 참여자 5,7 ).
"바로 일어나서 들을 수 있고(2-3), 가지 않아도 된다는 점에서는 되게 편한데(2-2), 저도 침대에서도 눕고 앉아 있 더라도 딴짓하고(7-4)."

이처럼 원격수업을 수강하면서 시간에 대한 중압감이 없고, 시 간절약에 대한 소중함을 깨닫고, 하지만 편안함을 추구하는 연구 참여자들의 경험을 '긴장감의 상실'이라고 명명하였다.

\section{침해당한 학습권}

대면강의에 익숙한 학생과 부모들은 원격수업을 들으면서 강의 에 집중하지 못하고 강의 내용을 얼마만큼 이해했는지에 대해 전 혀 알지 못한 채 마냥 강의를 듣고 있는 원격수업에 대해 학생(연구 참여자 $1,6,7,8,9$ )뿐 아니라 부모님들까지(연구 참여자 6) 등록금 이 아깝다고 하였다. 그래서 휴학을 고려하기도 하였다(연구 참여 자 1,3). 휴학을 고려한 이유로는 치료 실습을 대면으로 해 보고 싶 은 마음이 커서 휴학을 고려하였으나(연구 참여자 3) 현 상황이 쉽 게 끝날 것 같지 않으므로 빨리 졸업하라는 부모님들의 의견에 휴 학을 접은 경우도 있었다(연구 참여자 3).

“(등록금이) 아까워요(6-21), 내년에 실습을 그중요하니까 제대로 실습을 해보고 싶은데 코로나 때문에 어쨌든 상황이 바뀌고 있잖아요. 실습하는 것도 그래서 휴학을 하기 싫은데 해야되나라는 고민이 어쨌든 되긴돼요조금씩(1-29)."

이와 같이 원격수업을 들으면서 등록금이 아깝다고 생각하며 휴 학까지 고려한 연구 참여자들의 경험을 ‘침해당한 학습권’으로 명 명하였다.

\section{의지가 중요한 원격수업}

원격수업을 들으면서 눈치가 보여 질문도 못하고(연구 참여자 1), 틀린 답을 대답하면 대면강의 때보다 훨씬 더 창피함을 느꼈으며 (연구 참여자 4), 주목받는 것을 싫어하였다(연구 참여자 3). 또한 강 의 시간에 내 이름이 불리면 창피하기도 하였고(연구 참여자 2), 얼 굴을 보이는 것이 민망하기는 하지만 출석 인정을 위해 안 보일 수 는 없는 막막함을 경험하였다.

\section{“보여주기는 싫은데 안 보여줄수도 없고(6-25)."}

또한 원격수업 시간에 침대에 누워있거나(연구 참여자 6), 잠을 자거나(연구 참여자 4,7 ), 청소를 하거나(연구 참여자 3,10 ), 휴대폰 
을 본 다거나(연구 참여자 9,10$)$, 혹은 강의 시간에 몰래 간식을 먹 으면서(연구 참여자 10 ) 강의를 듣다 보니 정신이 분산되는 경험을 하였다.

"가장 큰 방해요소는 아무래도 핸드폰이요(9-2)."

그러다 보니 연구 참여자 3,8 은 $30 \%$ 정도는 한 귀로 듣고 한 귀 로 흘려버리고 $70 \%$ 정도만 강의를 들었다고 하였다. 그 결과 강의 내용을 알긴 하는데 다른 사람에게 설명은 못 할 것 같다고 하였으 며(연구 참여자 2), 강의와 관련된 내용이 아닌 휴강 내용까지도 학 과 대표에게 물어보는 경험을 하였다(연구 참여자 8,9 ).

"한 30\% 정도는 그냥 한 귀로 듣고 한 귀로 흘리는 수준 으로 가니까(3-5)."

하지만 연구 참여자 3 은 잠을 쫓기 위해 거실에서 강의를 듣기도 하였으며, 연구 참여자 4 는 화장실 가는 것도 참아가며 강의를 들 을 정도로 원격수업에 집중하려고 최대한 노력하는 모습을 보였다.

“교수님도 당황하시잖아요. 없어졌으니까. 그럴 때 조금 아이 그냥 참자... 다음 쉬는 시간까지 참자. 그런 것 같아요 (4-8)."

그래서 연구 참여자들은 원격수업은 본인의 의지에 달려있고(연 구 참여자 6), 친구들 신경을 쓰지 않고 나만 잘하기로 결심하였다 (연구 참여자 1). 또한 원격수업을 듣는 자신의 모습을 되돌아보게 되면서 수업에 적극적으로 참여하려고 노력하는 모습을 보였다.

“근데 그건 개인적으로 잘 해야 하지만 아닌 애들이 있을 것 같아요 처음에는 1 학기 때는 그것 때문에 스트레스를 받았어요. 근데 약간 내려놓은 걸로 나만 잘하면 되니까 그 냥 베낄 애들 베끼고 공유할 애들 공유하고 약간 나만 잘하 자(1-36)."

이처럼 원격수업에서 오는 막막함을 경험하고 정신이 분산되어 서 수업에 집중하지 못하지만 최대한 수업에 집중하려고 노력하면 서 참여하려고 노력하는 연구 참여자들의 경험을 '의지가 중요한 원격수업'이라고 명명하였다.

\section{환경적 차원}

\section{온라인 시스템 환경에 대한 불만족}

원격수업을 들으면서 인터넷 문제로 인해 수업시간에 갑자기 수 업이 중단되기도 하였으며(연구 참여자 2), 인터넷을 동시에 사용하 다 보니 속도가 줄어들고 화면 픽셀이 좋지 않았으며(연구 참여자 3), 유튜브 영상은 항상 끊겨서 내용을 이해하지 못하거나 자료를 거의 보지 못하는 경우도 있었을 정도로(연구 참여자 8) 원격수업 시 인터넷 환경이 불안정함을 경험하였다.

\section{"개인적으로 방에 공유기를 달고 노트북도 이제 많이 쓰 기에는 노후가 되고 원래 자주좀 꼻겼거든요(5-8)."}

또한 연구 참여자들은 마이크 조절에 대한 어려움을 경험하였 다. 연구 참여자 1 은 마이크를 다 켜 놓아서 시끄러운 경험을 하였 고, 연구 참여자 4,7 은 마이크 사용하는 것에 대한 불편함을 경험 하였다.

"어쩔 수 없는 상황이 만약 제 이름을 부르셨다 그러면 엄청 작게 말하다가 한소리 듣고 크게 애기하고 제 이름을 굳이 안 부르시면 정말 그것 때문에 수업이 끊기지 않는 이 상 굳이 켜고 애기하지는 않는 거 같아요(4-9)."

연구 참여자들은 원격수업을 들으면서 갑작스럽게 수업이 중단 되는 경험을 하였다. 연구 참여자 1,10 은 화면이 갑자기 정지되거나 화면에서 튕겨져 나가는 등 시스템적인 문제로 인해 강의 내용을 이해하지 못하는 어려움을 경험하였다. 특히, 수업 시간에 실제 임 상 현장 케이스를 영상으로 보여줄 때 영상이 끊겨도 대상자의 개 인정보가 포함되어 있어서 수업 시간 이외에 볼 수 있는 다른 대안 이 없다고 하였다.

"화면이 가끔 튕기거나 살짝 버퍼링 걸릴 때가 있는데 그 럴 때마다 교수님한테 말씀드릴 수가 없잖아요. 저만 튕긴 거 일 수도 있고? 하니까 다시 수업해달라 하기도 그렇고 애 들한테 물어볼 수가 없잖아요. 어 방금 튕긴 건가? 화면 안 넘어간 것 같은데 근데 수업 끝나고 보면 다같이 거기 못 들 었던 거고 이런 부분이 살짝 있긴 한데 이건 어쩔 수 없는 거 같고(1-6)."

또한 강의 링크가 잘 열리지 않아(연구 참여자 8) 친구로부터 링 크를 받아서 시청을 하기도 하였다(연구 참여자 6). 이런 경우 학생 
들은 교수님께 수업이 끊겨서 듣지 못했으니 다시 설명해 달라고 하 거나(연구 참여자 6), 친구에게 내용을 물어보거나(연구 참여자 10 ), 공유기를 다시 사서 문제를 해결하거나(연구 참여자 8), 해상도 를 낮춰서 인터넷이 덜 끊기게 하는 적극적인 해결 방법을 모색하 기도 하였다.

"개인 각자 링크를 보내가지고(6-92), 공유기를 다시 샀더 니 괜찮아요(8-57)."

이처럼 원격수업을 들을 때 인터넷 연결 환경이 불안정하거나 마 이크 조절의 어려움을 경험하거나 갑작스럽게 수업이 중단되거나 수업 링크가 잘 열리지 않았지만 적극적인 해결 방법을 모색한 경 험을 '온라인 시스템 환경에 대한 불만족'으로 명명하였다.

\section{적응하기 쉽지 않은 생활세계}

연구 참여자들은 원격수업을 들을 때 햇빛을 피해서 수업 듣기 가 어려웠으며(연구 참여자1), 강아지로 인해 수업에 집중하지 못할 때가 있으며(연구 참여자 5), 수업을 원룸에서 듣다 보니 수업 집중 도가 떨어지는 경우도 있으며(연구 참여자 2), 뒷배경이 신경 쓰여 서 수업에 집중하지 못할 정도로 혼란스러운 환경에서 원격수업을 듣고 있었다.

“그리고 딱 책상에서 듣고 싶은데 빛이 안 드는 자리도 있고 한데 얼굴이 안 보이니까 보여야 될 것 같아서 햇볕으 로 앉으면 아 난 타고 근데 커튼 치기에는 너무 안 보이니까 또 조명을 켜면 조명에 내가 또 타고 그냥 수업을 듣고 있는 상황 자체가 코로나 그거 때문에 너무 짜증이 나요(1-28).”

또한 주로 집에서 원격수업을 듣다 보니 가족들이 협조적이지 않 는 경우가 많았다. 연구 참여자 1 은 부모님이 원격수업을 가볍게 생 각하시기도 하였고, 연구 참여자 6 은 가족들이 원격수업에 대한 인 식이 부족해서 강의 도중인데도 밥 먹으라고 해서 난감한 경험을 하였고, 연구 참여자 7은 강의 도중에 문을 열고 들어오시는 가족 으로 인해 강의에 집중할 수 없었다.

“같이 사는데 지나가면 교수님께서 누구야? 이러시고 물 어보면 네 동거인입니다. 이렇게 하면 약간 좀 부끄럽고 나 한테 시선이 집중되는 것도 너무 싫고 그런 경우가 많은 것 같아요(2-35)."
이외에도 연구 참여자 2 는 시설에 살고 있는데 동거인이 강의 도 중에 돌아다녀서 강의에 집중하지 못하는 경험을 하였고, 연구 참 여자 9 는 여자 친구가 강의에 방해를 하여서 강의에 집중하지 못하 기도 하는 등 주변 사람들조차도 도움을 주지는 않고 강의에 방해 를 받은 경험을 하였다.

"저의 동거인들은 그냥 틀어 놓고 1학기 때는 밥 먹으려 고 요리를 하고 있었어요 그냥 요리했어요 요리하고 그러면 저 요기서 나도 줘 하고 나서 다 듣고 그렇게 요리하거나 침 대에 노트북을 들고 가서 침대가 아니라 같이 이렇게 한단 말이에요 노트북을 들고 와가지고 이렇게 탁 놔두고 자요 그냥 베개 위에 둬가지고 자요(2-47)."

특히 교수님 목소리가 울려서 강의에 집중하지 못하거나(연구 참여자 6), 교수님의 작은 목소리와(연구 참여자 10) 교수님의 목소 리가 자주 끓겨서 강의에 집중하지 못하는 경험을 하였다(연구 참 여자 8). 그리고 교수님이 강의 도중 전체 학생들의 음소거를 하지 않는 등 줌(Zoom) 사용에 미숙함이 있어서 강의 집중에 방해를 받 기도 하였다.

"교수님 목소리가 가끔 끊기거나 튕겨서 줌이 나가져버 려요(10-29).”

이처럼 배경환경도 혼란스럽고, 가족이나 주변인들이 비협조적 이며 교수님들조차도 줌 사용에 익숙하지 못해 강의 집중에 방해 받은 경험을 ‘적응하기 쉽지 않은 생활세계’라고 명명하였다.

\section{교과적인 차원}

\section{새로운 의사소통 방식의 출현}

연구 참여자들은 원격수업을 통해 생긴 의문점들을 공부 잘하 는 친구들에게 질문을 하거나(연구 참여자 6,9) 혹은 교수님들에 게 직접 질문을 하여 의문점들을 해소하고 있었다. 혹은 원격수업 을 들을 때 모르는 영어는 바로바로 인터넷으로 번역해서 공부하기 도 하였으며(연구 참여자 2), 못 들은 부분에 대해서는 바로 인터넷 을 검색하여 이해를 하였으며(연구 참여자 5), 집에서 강의를 들을 때 몸도 마음도 편할 정도로 원격수업에 적응하였다(연구 참여자 6). 그리고 이제는 원격수업 시간에 이해가 안 되면 마이크를 켜고 직접 교수님께 여쭈어볼 정도로 비대면수업에 적응을 해 나가고 있 었다. 그래도 이해가 가지 않으면 책이 옆에 있어서 바로 참조하여 강의를 들었고(연구 참여자 2), 교수님이 질문하면 공개적으로는 
대답을 못하지만 비밀 채팅을 이용하여 대답하기도 하는 등 궁금 한 점은 바로바로 해결하는 적극적인 모습을 보였다.

"네이버에 검색한다던가, 번역하거나(2-18)."

"귓말로 보내요 강의실에서는 귓말이 안 되잖아요(6-8)."

또한 대면강의에서는 과제를 하더라도 직접 만나서 하는 방법 밖 에는 없었지만 온라인상에서 밤새 과제할 수 있어서 매우 좋았고 (연구 참여자 4,8 ), 줌으로 소그룹 회의를 하는 경우가 많아지는 등 (연구 참여자 9) 모임의 방식이 대면강의 때보다 훨씬 다양해졌다.

"줌으로 회의하는 거 있는 거 많아진 거 같아요(9-31)."

그리고 치료 실습도 케이스가 희귀한 환자의 경우는 대면으로 치료하기가 어려운데 온라인 치료를 할 수 있어서 좋았고(연구 참 여자 4), 또한 청소년(연구 참여자 7) 및 성인은(연구 참여자 9) 온라 인 치료 실습을 해도 괜찮다는 생각을 하였다. 이처럼 연구 참여자 들은 대상에 따라 온라인 치료도 가능하다고 생각하였다.

"성인 치료 같은 경우에는 괜찮을 것 같다는 생각을 하 고 있는데(9-27)."

이처럼 원격수업을 들으면서 의문점이 들 때마다 바로바로 의문 을 해소하면서 비대면 강의에 적응해가며 다양한 모임 방식을 만들 고 또한 그전에는 전혀 생각하지도 않았던 온라인 치료도 대상에 따라 가능할 것 같다고 생각하는 연구 참여자들의 경험을 새로운 의사소통 방식의 출현'이라고 명명하였다.

\section{변화된 성적 시스템에 대한 불만}

원격수업을 하게 되면서 학교의 모든 시험은 온라인 시험으로 대 체를 하면서 학생들은 적응하지 못하고 불안해하는 모습을 보였 다. 온라인 시험을 보면 기억이 잘 나지 않고(연구 참여자1) 마이크 켜 놓고 시험 보는 것이 무척 힘들었으며(연구 참여자3) 그러다 보 니 연구 참여자 $1,3,8$ 은 온라인 시험이 부정행위가 많고 답을 공유 하는 친구들이 있을 수 있어서 온라인 시험이 공정하지 못하다고 생각하였다.

“컨닝한 사람도 많아요(8-30)."

그럼에도 연구 참여자들은 성적에 대한 관심이 많았다. 주로 성
적 산출에는 시험, 발표 그리고 출석이 포함된다. 하지만 연구 참여 자 2 는 온라인 시험이 어려울 것 같아 포기하는 마음이 들 정도로 시험 성적에 대한 중압감이 들었다. 그리고 연구 참여자 3 은 발표 준비가 잘 안된 팀에 대하여 화가 나기도 하였고 연구 참여자 5 는 비대면수업 때 조별 과제를 무시하는 애들 때문에 힘들었다고 하였 다. 또한 연구 참여자 4 는 후반부로 갈수록 출석 점검이 허술해져 서 싫다고 한 반면 연구 참여자 5는 출석 인정 요구 사항이 엄격해 져 힘들다고 하였다. 이처럼 연구 참여자들은 성적에 대한 나름대 로의 부담감을 가지고 있는 것으로 나타났다.

“어렵게 낼 거면 나 어차피 못 적을 텐데 이런 생각이 드 는 거 같아요 더 열심히 해야지 이게 아니라 내가 열심히 해 도 못 적을 거 같아 이렇게 생각이 드는 거 같아요(2-28)."

하지만 온라인 시험으로 인한 불공정성을 완화시키기 위해 학교 에서 상대평가의 비율을 높여주었고 이를 통해 중하위 학생들은 오히려 노력하지 않아도 성적이 좋아진 경우도 있으며(연구 참여자 6), 공부를 열심히 안 해도 성적 $\mathrm{B}$ 는 맞을 수 있으니까 공부를 안 하 는 것 같다고 하였다(연구 참여자 8). 즉 연구 참여자 $1,3,5$ 는 성적 비율이 유연해져서 살 것 같다고 하였다. 하지만 연구 참여자 10 은 시험 성적이 잘 나와도 이전에 비해 완벽하게 수업 이해를 못 한 것 같다고 자신을 자책하기도 하였다.

"시험점수가 뭐 $\mathrm{A}+$ 이 나와도 제가 완벽하게 해내지 못한 것 같은데 $\mathrm{A}+$ 받은 것 같은 것도 있고 그래서(10-42)."

이처럼 온라인 시험에 대해 공정하지 못하다고 느끼고 성적에 대 한 중압감도 느끼고 있지만 하향 평준화된 성적과 기대 이상으로 성적이 나와서 전반적으로 이전보다 공부를 더 안 하게 된다는 연 구 참여자들의 경험을 ‘변화된 성적 시스템에 대한 불만'으로 명명 하였다.

\section{가보지 않은 길에 대한 두려움}

언어치료청각재활을 전공하는 연구 참여자 2,4 는 실습 시 분위 기 환기시키는 것과 돌발 상황에 대처하는 법을 배우는 것에는 대 면이 더 좋을 것 같다고 느끼고 있었다. 그래서 대부분의 연구 참여 자들은 대면실습에 대한 기대를 하고 있었다.

"실습을 그 중요하니까 제대로 실습을 해보고 싶은데 코 로나 때문에 어쨌든 상황이 바뀌고 있잖아요. 실습하는 것 
도 그래서 휴학을 하기 싫은데 해야 되나라는 고민이 어쨌 든 되긴 돼요 조금씩(2-32)."

“아무래도 저희가 최종으로 하게 될 건 직접 환자를 만나 서 치료하는 거니까 온라인보다는 직접 만나서 경험을 해 보고 어떤 돌발상황이 생기는지 그런 것도 미리 경험해보 고 하는 게 제가 나중에 일을 할 때는 도움이 될 것 같아요 (4-20)."

하지만 상황 상 언어치료실습을 앞두고 있는 연구 참여자들은 아동과 라포 형성에 어려움이 있지 않을까 걱정하였고(연구 참여 자 5), 이미 원격실습을 실시하고 있는 참여자들은 반복되는 활동 을 하다 보니 대상자의 집중도가 현저히 떨어져 실습 대상자에게 미안한 감을 가졌으며(연구 참여자 6,10$)$, 온라인 원격실습 시 대상 자의 가족에게까지 피해가 될 수 있다고 느끼고 있다고(연구 참여 자 8)) 고충을 토로하였다.

"한없이 작아져야 돼 미안해 한 번 더 하자고(6-40), 되게 재밌는 걸 되게 많이 하고 싶어 하는데 그걸 못 해주니까 미 안하기도 하고(10-23)."

그러면서 원격실습 후 자격증을 취득한다 하더라도 허울뿐인 자 격증이 될 것 같고(연구 참여자 1) 청능사나 언어재활사로 자질이 부족할 것 같고 (연구 참여자 2) 또 속이 텅 빈 치료사가 될 것 같다 고(연구 참여자 3) 고민하고 있었다. 그래서 연구 참여자들은 현장 에 나가서 치료하는 것이 두렵고(연구 참여자 6), 학교에서 배운 것 을 임상에 응용하는 것이 어려울 것 같다고 하였다. 원격수업과 원 격실습을 한 후 자격증을 취득하고 임상 현장에 나가야 하는 연구 참여자들 모두 임상가로서의 자신의 모습이 염려스럽다고 하였다.

“전 좀 두려워요 이런 내가 치료를 할 수 있을까? 이번에 신경말언어장애 시험 볼 때 영상이 문제로 나왔는데 나름 벼락치기였지만 했다고 느꼈는데 와 하나도 모르겠는 거예 요 그래서 내가 할 수 있을까? 작년에 배웠던 것도 기억이 가물가물 한데 걱정이 되죠(1-41)."

이처럼 원격실습에 대한 고충이 있고 그러다 보니 대면실습을 기 대하면서도 원격수업 후 임상가로서 생활해야 하는 자신의 모습을 염려하는 연구 참여자들의 경험을 “가보지 않은 길에 대한 두려움" 이라고 명명하였다.

\section{논의 및 결론}

본 연구에서는 일년여간의 실시간 원격수업이 이루어진 후, 포커 스 그룹 인터뷰를 통해 언어치료청각재활 전공 학생의 실시간 원격 수업을 활용한 이론 및 실습 수업에 대한 인식을 살펴보고, 이를 토 대로 실시간 원격수업의 효과적 시행에 대한 시사점들을 논의해보 고자하였다.

인터뷰 분석 결과, 190 개의 의미단위, 44 개의 하위범주, 10 개의 핵심범주가 도출되었고, 이 중 10 개의 핵심 범주를 개인적, 환경적, 교과적 차원으로 분석을 하였다. 분석 결과를 구체적으로 살펴보 면 다음과 같다.

첫 번째, 개인적 차원에서 학생들은 실시간 원격수업의 학습 효 과는 전적으로 학습자의 의지에 달려있다고 여겼다. 수업이 실시간 으로 진행되긴 하지만 교수자가 같은 공간에서 학생들을 대면하고 있는 상황이 아니기 때문에 교수자의 통제력이 대면수업보다 상대 적으로 낮아질 수밖에 없으므로 원격수업 환경 구축 및 학습 태도 는 학습자의 의지에 따라 좌우될 가능성이 크다고 하겠다. 통학에 소요되는 시간이 절약됨으로써 집에서 편안하게 수업을 들을수 있 지만 이로 인해 학생들 대부분 강의에 대한 집중력이 저하되고 주 의가 산만해진다고 하였다. 이와 같은 결과는 공과대 학생들을 대 상으로 한 Lim, Kim과 Kim (2012)의 연구에서 원격수업이 학습자 의 흥미나 집중력을 유지하는 데 부정적인 영향을 미친다고 했던 결과와 유사하였다. 수업에 대한 긴장감이 줄어들고 나태해지면서 무기력감이 증가한다고 하였다. 또한 학교에 나오지 않으니 학교에 대한 소속감이나 동기들과의 유대감이 약해지면서 학습에 대한 흥 미도가 저하되고 도서관 등 학교 시설물을 이용하지 못하니 등록 금이 아깝다는 생각이 들면서 휴학을 고려해보게 된다고 하였다.

두 번째, 환경적 차원에서는 갑작스럽게 실시간 원격수업이 시작 되다 보니 학교 시스템이나 학생 개개인이 수업에 대한 준비가 미흡 했다는 것을 엿볼 수 있었다. 대규모 수업 도중 영상이 끊기거나 교 수자의 말소리가 울리는 등 온라인 시스템 환경이 수업을 방해하 는 요인이 되었고 대상자의 평가나 치료 장면을 영상으로 봐야 하 는 상황에서 수업의 중요한 부분을 놓치는 경우가 많았다. 이를 해 결하기 위해 수업을 듣는 장소를 바꾸거나 공유기 교체 등의 인터 넷 환경을 개선하기 위한 학생들의 개인적인 노력을 요하는 것으로 나타났다. 주변 소음이나 같이 사는 동거인 등 생활 환경 자체가 수 업에 또 다른 방해가 되기도 하였고 교수자의 조작 미숙함 또한 문 제가 된다고 하였다. Kang과 Kim (2011)의 연구에서도 매체 활용 의 어려움이 학습의 흐름을 방해하고 결과적으로는 학업 성취에 부정적인 영향을 가져올 수 있다고 하였다. 그러므로 이를 위해 안 
정적인 서버 구축이나 인터넷 사용이 어려운 학습자를 위한 고려, 교수자들의 적극적인 온라인 강의 기술의 활용 등이 요구된다고 할수 있다(Lee, 2020).

세 번째, 교과적 차원에서는 원격수업에 적응하면서 수업 시간 중에 이해하지 못한 내용에 대해 바로 인터넷 검색을 하거나 수업 에 방해를 주지 않으면서 채팅창을 이용해서 수업 중 교수님께 바 로 질문을 할 수 있다고 하였다. 또한 조별 과제를 진행함에 있어서 오프라인으로 만나지 않아도 원격 화상회의 소그룹 시스템을 이용 하여 조별 과제를 진행하는 새로운 경험을 하게 되었다고 하였다. 원격수업은 강의 진행뿐만 아니라 학습자 요구에 따른 피드백, 소 그룹 회의실을 활용한 토론 등 다양한 상호작용 기회를 줌으로써 교수와 학생뿐만 아니라 학생들끼리의 소통을 원활하게 할 수 있다 고 하였다(McCormack, Easton, \& Morkel-Kingsbury, 2014). 그러 나, 원격수업의 출석에 대한 규정이 명확하지 않으며, 온라인 시험 을 통한 평가는 상대평가에 대한 규제를 완화했음에도 불구하고 공정성에서 많은 문제가 있다고 불만을 토로하였다. Song과 Kim (2020)의 연구에서도 수업 평가 및 관리가 원격수업 만족도에 영향 을 미치는 주요한 변인이라고 하였다. 변화된 수업 운영 방식에 시 스템적으로 준비가 되지 않은 상황에서 원격수업이 진행되다 보니 학교 차원에서 구체적인 평가 방법이나 학점 체계 등의 가이드라인 을 제공하지 못함으로써 혼란을 야기하였고 학생들은 이에 대한 불만이 있었던 것으로 보인다.

언어치료청각재활은 이론과 임상 실무를 다루는 학문인 만큼 교 육과정에서 실습이 매우 중요한 비중을 차지한다. 그러나 대면실습 에 어려움이 생기면서 임상실습 역시 원격으로 진행하는 방식이 도 입되었다. 그동안 대면으로만 실시되던 방식을 벗어나 원격실습 시 스템을 도입함으로써 실습의 범위를 확대시켰다는 의미도 있었으 나 사람을 대상으로 하는 일이다 보니 대상자와 라포 형성의 어려 움을 호소하며 원격실습이 실질적인 실무 경험에 도움이 되지 못 할 거라는 걱정과 두려움을 갖고 있었다. 이는 상담 전공 대학원생 을 대상으로 한 Park과 Lee (2021)의 연구에서도 원격수업으로 실 습의 기회가 줄어 취업에 대한 불안감을 가지고 있다고 하였으며 비 대면 환경에서의 실습을 하기 위해서는 상호작용과 효과적인 연습 을 위한 지침서가 필요하며 대면-비대면 실습을 병행할 때 학습 효 과가 높으며 이론과 실제를 통합한 피드백을 통한 성장을 촉진하 는 학습 전략이 필요하다고 하였다.

코로나19 이전에도 이러닝 혹은 비대면수업에 대한 연구들은 진 행되어 왔다. 실시간 원격수업은 지역적으로 멀리 떨어져 있는 사람 들을 동시에 연결하여 쌍방향 의사소통이 가능하게 하고, 기존의 전통적인 대면수업과 유사한 교육적 성과를 얻게 한다는 점에서
교육적 잠재성이 평가되고 있다. 그러나 코로나 19 상황이 비대면 원 격수업을 선택이 아닌 필수로 만들었다. 4 차산업혁명시대의 창의 융합인재 양성을 위해 다양한 전공자들이 서로 활발하게 상호작 용할 수 있고 교수자들이 서로 전문적 지식을 적극적 공유할 수 있 으며 글로벌 교육이 점차 확대되어감으로써 앞으로 원격강의, 하이 브리드 강의가 더 활발하게 이루어질 것으로 보인다. 또한, 코로나 19 로 인해 수행된 언어치료 분야의 선행연구에서 하이브리드 원격 실습 및 원격치료 효과와 필요성을 보고하였고(Khoza-Shangase et al., 2021), 청각학 분야에서도 코로나 19 이전에는 $85 \%$ 의 청각학자 가 원격으로 진료를 해본 경험이 없다고 하였으나 이제는 원격으로 하는 청력 검사 및 피팅, 청력재활 등의 서비스를 해야 하는 시대가 되었다는 보고를 통해 원격 진단 및 원격치료의 필요성을 보고하였 다(Coco, 2020).

본 연구는 코로나 19 시대에 실시간 원격수업에 대한 언어치료청 각재활학과 학생들의 다양한 의견과 욕구를 확인하였다. 원격수업 의 문제점들을 해결하여 효과적인 교수 학습 전략을 마련하고 언 어치료청각재활 분야의 전문가 양성을 위한 다각도의 연구가 요구 됨을 시사한다. 원격수업이 교육적으로 잘 활용되기 위해서는 원격 수업을 수행하기 위한 구체적이고 실질적인 교수-학습 지원이 필요 하다는 것을 인식하고, 프로그램이 학습자의 어떤 부분에 기여하 여 학습 효과가 나타나는지에 대한 실증적 연구가 이루어질 필요 가 있다. 또한, 언어치료청각재활 전공의 특성상 SW/IT 디지털분야 와 융합하여 창의융합인재 양성이 가능한 분야이므로 주변 학문, 테크놀로지 활용, 공유대학 프로그램을 활용하여 창의융합인재 양성을 위한 미래교육체제 구축 기반도 필요하다. 이러한 연구결과 를 토대로, 본 연구가 언어치료청각재활을 전공하는 교수자와 학습 자 모두에게 비대면 원격수업의 교육 효과를 높이기 위한 기초 자 료로 활용되기를 바란다.

본 연구는 다음과 같은 제한점을 가지고 있어 후속 연구를 위한 제언은 다음과 같다.

첫째, 본 연구는 적은 수의 비교적 성적이 좋은 학생들로 이루어 진 참가자를 대상으로 하여 포커스 인터뷰 방식을 실시하였으므로 다양한 전공의 대학생들에게 일반화하기에는 어려움이 있다. 언어 치료와 청각재활을 전공하는 다양한 학생들의 인식을 파악하는 후속 연구가 이루어져야 할 것이다.

둘째, 본 연구는 실시간 원격 화상수업만을 경험한 학생들을 대 상으로 하였으므로 원격수업이라고 하더라도 동영상을 통한 원격 수업이나 동영상 수업과 병행해서 실시하는 하이브리드 원격수업 의 결과와는 차이가 있을 것이므로 원격수업의 다양한 형태에 대 한 연구들과 차이들을 연구해볼 필요가 있다. 
셋째, 실습에 대한 질문을 다루기는 하였으나 언어치료와 청각재 활 분야의 다양한 실습 과목에 대한 세부적인 원격실습 경험을 다 루지는 못하였다. 다양한 실습 수업에 대한 원격수업의 학습 지원 방법을 위한 프로그램과 역량 개발 등에 대한 연구가 필요하다.

넷째, 본 연구는 학습자 중심의 경험을 연구하였으므로 교수자 입장에서의 원격수업에 대한 이해, 만족도 등의 직접적 경험 연구 도 교육 효과를 검증하는데 필요할 것으로 생각된다.

다섯째, 학생의 수업에 대한 만족도에 영향을 주는 요소들, 즉 교 수자와의 관계, 평가 방법, 수업 유형, 교과목 유형, 개인적인 여건과 의 상관관계에 대한 연구도 필요할 것으로 판단된다.

\section{REFERENCES}

Blackwell, P. B., Roach, C. M., \& Baker, B. M. (2002). Satisfaction of graduate students involved in a web-based learning experience in speech-language pathology. Contemporary Issues in Communication Science and Disorders, 29, 125-131.

Cho, E. S. (2020). Untact classes in post Covid-19: the roles and challenges of educational Technology. Journal of Educational Technology, 36(3), 693-713.

Choi, M. N., \& Roh, H. L. (2011). Effect of the registration motivation and learning satisfaction on persistent intention in e-learning courses of university. Journal of Educational Technology, 27(4), 653-673.

Coco, L. (2020). Teleaudiology: strategies, considerations during a crisis and beyond. Hearing Journal, 73(5), 26-29

Do, J. W. (2020). An investigation of design constraints in the process of converting face-to-face course into online course. Journal of Education \& Culture, 26(2), 153-173.

e-dhnews. (2021). Selected by 8 associations for 'Digital Innovation Sharing University'... Implemented 46 university projects. Retrieved from http:// www.dhnews.co.kr/news/articleView.html?idxno=140295.

Fredericksen, E., Pickett, A., Shea, P., Pelz, W., \& Swan, D. (2000). Student satisfaction and perceived learning with on-line courses: principles and examples from the SUNY Learning network. Journal of Asynchronous Learning Networks, 4(2), 7-41.

Kang, M. S., \& Kim, H. Y. (2011). Case study on the implementation of e- learning using teleconference application: Focusing on the learners' perception and factors that predict attitude of learning participation and program evaluation. The e-Business Studies, 12(13), 3-25.

Khoza-Shangase, K., Moroe, N., \& Neille, J. (2021). Speech-Language Pathology and Audiology in South Africa: clinical training and service in the era of COVID-19. International Journal of Telerehabilitation, 13(1), 1-30.

Kim, H. J. (2020). An exploration on non-face-to-face Korean class experience of foreign undergraduate students: Focusing on real-time online class utilizing Zoom. Journal of Humanities and Social Sciences 21, 11(4), 16791692.

Krimm, H., Schule, M. C., \& Brame, C. (2017). Viability of online learning for ensuring basic skills in speech-language pathology. Perspectices of the ASHA Special Interest Groups, 2(10), 49-58.

Krippendorff, K. H. (2003). Content analysis: an introduction to its methodology 2nd edition, Sage Publications, Inc.

Lee, H. (2020). A study on the perception of e-learning by college students majoring in music. Research in Music Pedagogy, 21(2), 177-197.

Lim, C., Kim, H., \& Kim, D. (2012). Analysis on learners' satisfactions of video conferencing in global engineering education. Journal of Engineering Education Research, 15(4) 66-75.

Lu, D., Lin, Z., \& Li, Y. (2009). Effects of a web-based course on nursing skills and knowledge learning. Journal of Nursing Education, 48(2), 70-77.

McCormack, J., Easton, C., \& Morkel-Kingsbury, L. (2014). Educating speechlanguage pathologists for the 21st century: course design considerations for a distance education master of speech pathology program. Folia Phoniatrica et Logopaedica, 66(4-5), 147-157.

Park, J. S., \& Lee, S. H. (2021). A study on the type of perception graduate students' online class using Q methodology: graduate students majoring in counseling and coaching. Journal of Education \& Culture, 27(1), 77-99.

Song, S. Y., \& Kim, H. K. (2020). Exploring factors influencing college students' satisfaction and persistent intention to take non-face-to-face courses during the COVID-19 pandemic. Asian Journal of Education, 21(4), 1099-1126.

Wang, A. Y., \& Newlin, M. H. (2000). Characteristics of students who enroll and succeed in psychology Web-based classes. Journal of Educational Psychology, 92(1), 137-143. 


\section{국문초록}

\section{언어치료청각재활 전공 학생의 실시간 원격수업 경험에 대한 포커스 그룹 질적연구}

\section{김지연 · 탁평곤 · 이수복}

우송대학교 언어치료청각재활학과

배경 및 목적: 본 연구의 목적은 코로나 19 대유행 하에서 수행된 zoom을 활용한 실시간 원격수업 경험과 관련하여 언어치료청각재활 을 전공 한 학생들의 인식을 살펴보고 향후 비대면 원격수업의 효과를 높이기 위한 방안을 찾고자 하였다. 방법: 포커스 그룹 인터뷰는 언어치료청각재활을 전공하는 10 명의 학생(각 5 명)을 대상으로 2 회 진행되었다. 연구 참여자들은 2020 년 1 학기부터 2 학기까지 실시간 원격수업을 수강한 언어치료청각재활학과 2,3 학년 학부생들이었다. 포커스 그룹 인터뷰의 질문지는 상호작용, 강의 내용, 강의 시스템, 전반적인 의견 등의 4 영역 21 개 질문으로 제작하였고 집단별로 90 분간 인터뷰를 진행하였다. 자료분석은 강의 경력이 10 년 이상인 언어 치료청각재활학과 교수 3명이 실시하였고 내용분석은 Krippendorff (2003)가 제안한 절차에 따라 분석하였다. 결과: 연구 참여자들의 실시간 원격수업 경험을 오픈 코딩하여 분석한 결과, 190 개의 의미단위, 44 개의 하위범주, 10 개의 핵심범주가 도출되었다. 그리고 10 개 의 핵심범주는 3 개의 차원인 개인적 차원, 환경적 차원, 교육적 차원으로 구분되었다. 연구결과는, 코로나 19 기간 동안 학생들의 비대면 원격수업에 대한 다양한 의견과 욕구를 확인하였다. 첫째, 개인적 차원에서는 실시간 원격수업의 학습 효과는 전적으로 학습자의 의지 에 달려있다고 여겼다. 둘째. 환경적 차원에서는 갑작스럽게 실시간 원격수업을 도입하면서 학교 시스템뿐만 아니라 학생 개개인이 원격 수업에 대한 준비가 미흡했다고 인식하였다. 세 번째, 교과적 차원에서는 수업 시간 중에 이해하지 못한 내용에 대해 바로 인터넷 검색 을 하거나 채팅창을 이용해서 수업 중 교수님께 바로 질문을 할 수 있는 편리함과 더불어 원격수업의 평가 및 관리 체계에 대한 불만족 을 언급하였다. 논의 및 결론: 본 연구의 결과는 코로나 19 이후, 교수자와 학생의 안전보장과 질 높은 비대면 원격교육을 제공하기 위해 원격수업을 위한 교수학습법 개선이 필요하며 언어치료청각재활 분야의 창의융합형 실무전문가 양성을 위한 교육체제 구축 등의 다각 도의 연구가 필요함을 시사하였다.

핵심어: 코로나19, 언어치료청각재활학과, 실시간 원격수업, 비대면수업, 포커스 그룹 인터뷰, 질적연구

이 연구는 2021년도 우송대학교 교내학술연구조성비 지원에 의해 이루어짐.

\section{참고문헌}

강민석, 김혜영 (2011). 원격화상세미나 소프트웨어를 활용한 이러닝 운영 사례연구: 학습자 인식, 태도 및 강의평가 예측요인을 중심으로. e-비즈니스 연구, 12(13), 3-25.

김현주 (2020). 외국인 학부생의 비대면 한국어 수업 경험에 대한 탐색: 줌(Zoom)을 활용한 실시간 온라인 수업을 중심으로. 인문사회 21, 11(4), 1679-1692.

도재우 (2020). 면대면 수업의 온라인 수업 전환과정에서 발생하는 설계 장애물에 대한 탐색. 교육문화연구, 26(2), 153-173.

박정서, 이상희 (2021). Q 방법론을 활용한 대학원생의 온라인 수업에 대한 인식 유형 연구: 상담 및 코칭 전공 대학원생을 중심으로. 교육문화연구,

$27(1), 77-99$.

송수연, 김한경 (2020). 언택트 시대의 대학교육: 코로나19에 따른 비대면 강의 만족도와 수강지속 의사에 영향을 미치는 요인에 관한 연구. 아시아교

육연구, 21(4), 1099-1126.

이희숭 (2020). 음악전공 대학생들의 온라인 수업에 대한 인식 연구. 음악교수법연구, 21(2), 177-197.

임철일, 김혜경, 김동호 (2012). 글로벌 공학교육의 원격화상강의에 대한 학습자 만족도 분석. 공학교육연구, 15(4), 66-75.

최미나, 노혜란 (2011). 대학 이러닝에서 수강동기, 학습만족도가 지속수강 의사에 미치는 영향 교육공학연구, 27(4), 653-673. 
JiYoun Kim, et al. • Qualitative Analysis on Online Learning

e-대학저널 (2021). ‘디지털 혁신공유대학' 8개 연합체 선정... 46개 대학 사업수행. 서울: e-대학저널.

\section{ORCID}

김지연(제1저자, 교수 https://orcid.org/0000-0003-4259-7784); 탁평곤(공동저자, 교수 https://orcid.org/0000-0001-7498-7328);

이수복(교신저자, 교수 https://orcid.org/0000-0001-6942-4635) 